Biol. Stud. 2014: 8(1); 137-148 • DOI: https://doi.org/10.30970/sbi.0801.317

www.http://publications.Inu.edu.ua/journals/index.php/biology

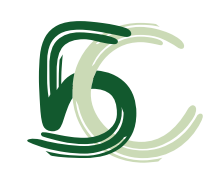

UDC: $582.28+582.29$

\title{
CARBONEA IN UKRAINE
}

\author{
M. Pirogov ${ }^{1}$, N. Chepelevska', J. Vondrák ${ }^{2}$ \\ ${ }^{1}$ Ivan Franko National University of Lviv, 4, Hrushevskyi St., Lviv 79005, Ukraine \\ e-mail: nikola.pirogov@gmail.com \\ ${ }^{2}$ Institute of Botany, Academy of Sciences, Zámek 1, CZ-252 43 Průhonice, Czech Republic \\ Faculty of Science, University of South Bohemia, Branišovská 31, CZ-370 05 \\ České Budějovice, Czech Republic \& Faculty of Environmental Sciences \\ Czech University of Life Sciences Prague \\ e-mail: j.vondrak@seznam.cz
}

Carbonea (Lecanoraceae, Ascomycota) genus contains about 20 species of lichenized and lichenicolous fungi. Four species among them are known in Ukraine: Carbonea assimilis (Körb.) Hafellner et Hertel, C. vitellinaria (Nyl.) Hertel, C. invadens (H. Magn.) M.P. Andreev, and C. vorticosa (Flörke) Hertel. We report about five taxa of Carbonea in Ukraine in the Carpathians and the Crimean peninsula: C. aggregantula (Müll. Arg.) Diederich \& Triebel, C. supersparsa (Nyl.) Hertel (both new to Ukraine), C. assimilis (identification not confirmed by us), C. vitellinaria and C. vorticosa. We provide a description of the genus and characterize the Ukrainian taxa. We also present the key for determination of Carbonea involving species known in Ukraine and also those that might eventually be found in Ukraine. Morphologically, species similar to Carbonea from other genera are also included in the determination key. Carbonea invadens was incorrectly recorded from Ukraine, the respective voucher specimen is Scoliciosporum intrusum (Th. Fr.) Hafellner, poorly known taxon similar to Carbonea that is new for Ukraine. We also provide a characterization of Scoliciosporum intrusum and included it into the key.

Keywords: alpine lichens, lichenicolous fungi, biodiversity, Carpathian mountains, Chornogora, Petros, Scoliciosporum intrusum.

Four species of the Carbonea genus (Lecanoraceae, Ascomycota), C. assimilis (Körb.) Hafellner et Hertel, C. vitellinaria (Nyl.) Hertel, C. invadens (H. Magn.) M.P. Andreev and C. vorticosa (Flörke) Hertel, have been known in Ukraine [2; 14]. Records of Carbonea assimilis and $C$. vitellinaria are from Crimea [5; 12], C. invadens was recently recorded from the Carpathians [14], and C. vorticosa, was recorded by Oxner [3; sub Lecidea vorticosa (Flörk.) Körb.] from the Carpathians. During a botanical expedition to the Chornogora Mts (part of the Ukrainian Carpathians) in 2011, the first author collected four taxa of Carbonea: Carbonea vitellinaria, C. vorticosa, and two species new 
to Ukraine: C. aggregantula and C. supersparsa. In addition, the herbarium voucher to the Ukrainian record of Carbonea invadens (CBFS JV6774) was critically revised and identified as Scoliciosporum intrusum.

In the „Lichen flora of Ukraine” [3], the Carbonea genus is not included, so we provide a description of the genus, identification key and characterizations to the Ukrainian species and also the characterization of Scoliciosporum intrusum, the taxon which is similar to Carbonea. Phenotypic characterizations of taxa are made exclusively on grounds of the Ukrainian material; the only exception is Carbonea assimilis, because did not see its Ukrainian specimen. Data on ecology and distribution of taxa are adopted from the cited literature.

\section{Carbonea (Hertel) Hertel}

\section{Mitt. bot. StSamml., Münch. 19: 441 (1983)}

Type of the genus: Carbonea atronivea (Arnold) Hertel

Life forms: Lichen-forming or non-lichenized fungi, often lichenicolous. Thallus: crustose, \pm superficial, continuous to dispersed, areolate, sometimes immersed or inconspicuous, especially in non-lichenized lichenicolous species. Photobiont: chlorococcoid green algae (Pseudotrebouxia) or absent. Ascomata: lecideine apothecia, immersed to sessil, dispersed to aggregated, round or deformed by pressure when growing tightly together, black to brownish-black, glossy or matt. Thalline exciple: absent. True exciple: \pm well developed, narrow and raised, but sometimes diminishing in older ascomata, black, gray or green but always dark, \pm carbonized, in marginal part darker than in inner part, opaque. Disc: slightly concave to flat or convex, without pruina. Epihymenium: intense blue-black-green to aeruginose. Hymenium: colourless in lower part to vivid blue-green above. Hypothecium: colourless, pale brownish-yellow, bluegreen or dark brown-black. Hamathecium: paraphyses simple, 1-2 $\mu \mathrm{m}$ thick, apical cells swollen to $3.5 \mu \mathrm{m}$ wide, coherent in a gelatinous matrix. Asci: 8-spored, clavate, Lecanora-type. Ascospores: colourless, simple, oblong-ellipsoid to ovoid-fusiform. Conidiomata: pycnidia, immersed. Conidiogenous cells: elongate, ampulliform, enteroblastic. Conidia: curved, thread-like, simple, colourless (Fig. 1).

Diagnostic characteristic: brown to black lecideine apothecia with persistent or disappearing margin; carbonized exciple (in most species); asci of the Lecanora-type with tall apical dome; blue-green color of the epihymenium and upper part of hymenium; non-septate ascospores, usually narrowly ellipsoid.

The Carbonea species were members of an aggregate genus Lecidea s. lat. in the past, but Hertel [10] separated them into an independent subgenus Carbonea within Lecidea. The carbonized exciple with cellular structure (paraplectenchymatous) in lower part and reddish brown hypothecium was used to separate this subgenus from other subgenera of Lecidea [10]. Hertel in 1983 [11] raised Carbonea to the generic level on the ground of its Lecanora-type ascus, and placed it to the family Lecanoraceae s. lat. The position of Carbonea in Lecanoraceae was also supported by phylogenetic data [6].

Hertel [11] included only four species of lichenized and lichenicolous fungi into the genus Carbonea, but now it contains about 20 species [13]. Carbonea is a widely distributed genus in temperate and mountain regions of Europe, Asia, Northern and Southern America and Australia. Most of species have arctic-alpine and boreal biases.

ISSN 1996-4536 (print) • ISSN 2311-0783 (on-line) • Біологічні Студії / Studia Biologica • 2014 • Том 8/№1 • C. 137-148 
Carbonea species are generally lichenicolous, but some taxa are free living, epilithic or very rarely epiphytic.

Key to the Ukrainian species of Carbonea. Morphologically similar species to Carbonea from other genera are also included in the determination key. Taxa potentially occurring in Ukraine are in brackets.
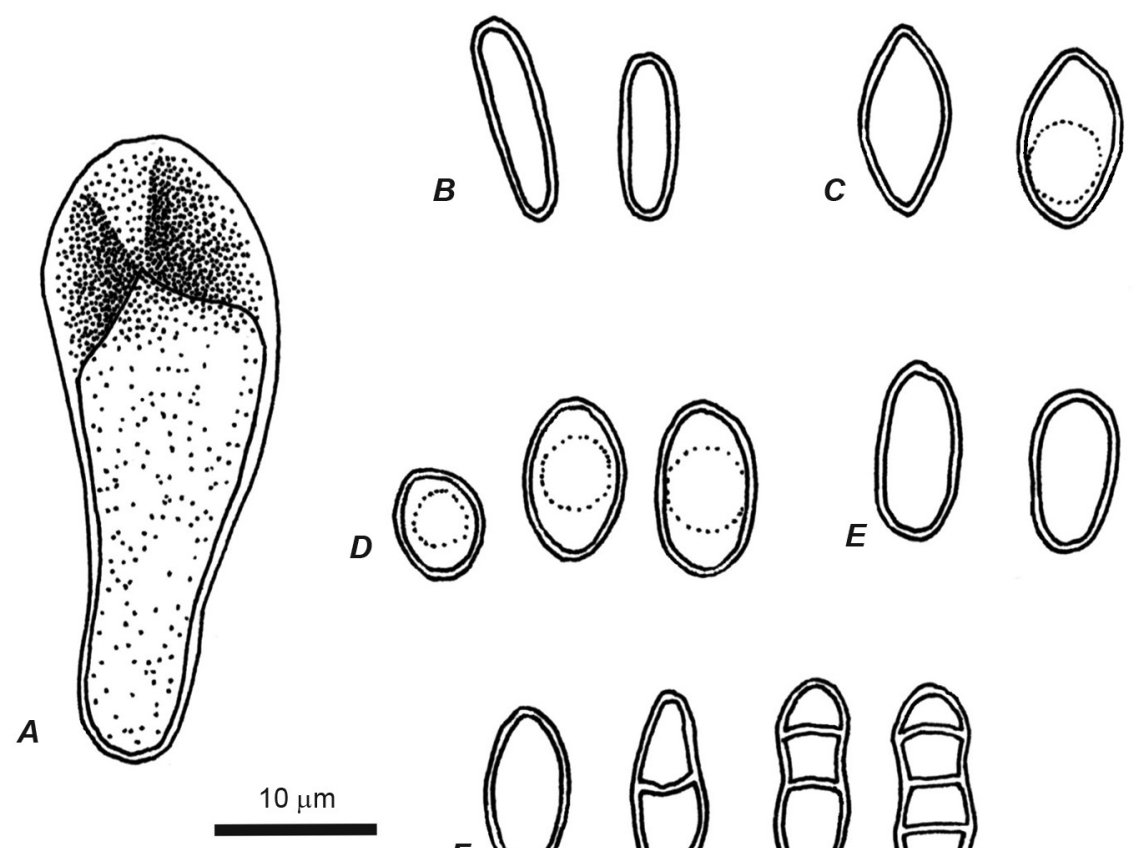

D
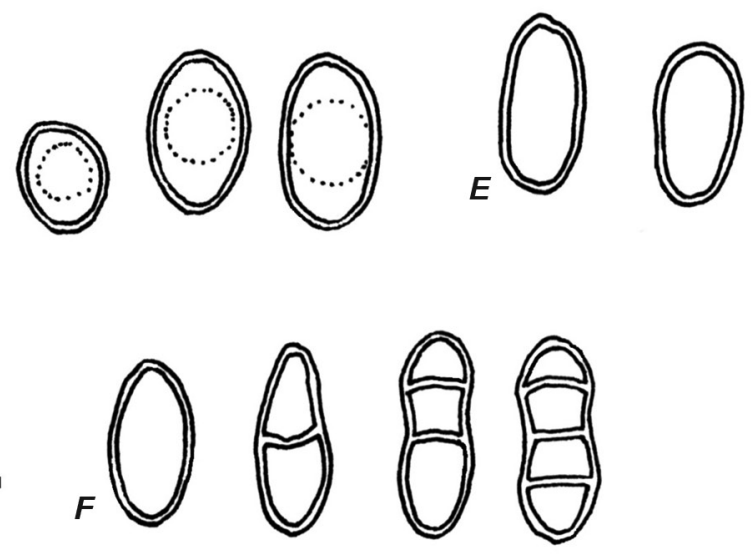

Fig. 1. Ascus of Carbonea aggregantula with tall apical dome of the Lecanora-type $(A)$; ascospores of $C$. aggregantula $(B)$; of $C$. supersparsa $(C)$; of $C$. vitellinaria $(D)$; of $C$. vorticosa $(E)$; and of Scoliciosporum intrusum $(F)$. Bar $10 \mu \mathrm{m}$

Pис. 1. Сумка Carbonea aggregantula з високим апікальним апаратом Lecanora-типу $(A)$; аскоспори $C$. aggregantula $(B)$; C. supersparsa $(C)$; C. vitellinaria $(D)$; $C$. vorticosa $(E)$; i Scoliciosporum intrusum $(F)$. Шкала 10 мкм

1. Lichenicolous 2.

- Free-living 9.

2. Thallus absent 3.

- Thallus usually distinct 7.

3. Asci Bacidia-type. Ascospores simple, 8-12×3-5 $\mu \mathrm{m}$. Apothecia lecideine, $0.2-$ $0.4 \mathrm{~mm}$ in diam., flat to slightly convex, most of apothecia with visible margin, not agglomerated, often arranged in rows along the fissures between the areoles of the host. Hymenium colourless to brown. Epihymenium blue-green-black. Host Rhizocarpon geographicum. It is known only from Greece. Systematic position unknown [8] (may be found in the Crimean Peninsula)

- Asci Lecanora-type ("Lecidea" halacsyi J. Steiner) 
4. Hypothecium dark-brown or brown-black. Ascospores narrow and elongated, 9-12×2-4 $\mu \mathrm{m}$. Host Lecanora polytropa Carbonea aggregantula

- Hypothecium light, colourless, yellow to pale brown

5. Hypothecium colourless, but after $\mathrm{KOH}$ treatment purple-red $\rightarrow$ violet/brown. Epihymenium olive-black, $\mathrm{KOH}+$ blue. Exciple brown in section but not carbonized, with clearly radial hyphae. Ascospores $12-15 \times 4-5 \mu \mathrm{m}$. Young apothecia flat and with margin, mature apothecia convex and without margin. Host Rhizocarpon umbilicatum [7] (known from Austria, may be found in the Ukrainian Carpathians)

(Carbonea

herteliana Hafellner \& Matzer)

- Hypothecium $\mathrm{KOH}-$. Exciple carbonized, green-black or brown-black in section ..

6.

6. Ascospores ellipsoid with rounded apices, 7-11×4-6 $\mu \mathrm{m}$. Host Candelariella vitellina or rarely the species of genera Lecanora, Lecidea and Rhizocarpon

\section{Carbonea vitellinaria}

- Ascospores ovoid-fusiform with pointed apices, 7-12×4-6 $\mu \mathrm{m}$. Host Lecanora polytropa, rarely Lecanora spp. or Rhizoplaca spp.

Carbonea supersparsa

$7(2)$. Thallus white, squamulous, with black apothecia in the central part. Apothecia aggregated, rounded but often deformed by pressure, flat or slightly convex. Hypothecium dark brown. Exciple black, with red-brown lines towards hypothecium (visible on thin sections). Ascospores oblong-ellipsoid 8-15×3.5-6 $\mu \mathrm{m}$. Free-living on limestone or lichenicolous on calcicolous Lecidella (widespread in Europe in a subalpine and alpine and dry continental regions in nutrient-rich communities; may be found in the Carpathians, Crimea and in the steppe zone)

(Carbonea atronivea (Arnold) Hertel)

- Thallus brown or grey, glossy or matt, crustose but not squamulous. Hypothecium colourless 8.

8. Thallus bullate-areolate, pale to dark brown, glossy. Apothecia with persistent margin. Exciple dark-brown in section. Ascospores ellipsoid to ovoid, 8-15×5-9.5 $\mu \mathrm{m}$, simple

Carbonea assimilis

- Thallus rimose-areolate, thin, grey, olive to black. Apothecia with indistinct margin. Exciple black-blue-green in section. Ascospores oblong-ellipsoid with obtuse apices, simple to 1-3-septate, 9-15×3-5 $\mu \mathrm{m}$ Scoliciosporum intrusum

9(1). Hypothecium red-brown to black-brown 10.

- Hypothecium colourless or pale grey, yellowish, brownish, brown-yellow

10. Thallus white, squamulous, with black apothecia grouped in the central part .... (Carbonea atronivea) (see the point 7).

- Thallus granular, whitish, grey or cream, frequently reduced or absent, sometimes only black prothallus visible, apothecia dispersed

Carbonea vorticosa

11. Thallus bullate-areolate, pale-brown to dark-brown, glossy. Exciple dark-brown Carbonea assimilis

- Thallus rimose-areolate, matt 12.

12. Thallus thin, grey, olive to black. Apothecia numerous, without margin. Exciple black-blue-green in section. Ascospores 9-15×3-5 $\mu \mathrm{m}$, oblong-ellipsoid with obtuse apices, simple to $1-3-$ septate

Scoliciosporum intrusum

ISSN 1996-4536 (print) • ISSN 2311-0783 (on-line) • Біологічні Студії / Studia Biologica • 2014 • Том 8/№1 • C. 137-148 
- Thallus white, yellowish, pale-grey, granular, granular-areolate, $\mathrm{KOH}+$ yellow. Areoles flat to convex. Apothecia numerous, flat to convex with clear margin. Exciple pale grayish, gray-brown, yellow-brown to orange in section. Ascospores ellipsoid, simple, 8-15×4-7 $\mu \mathrm{m}$, with obtuse apices (known from siliceous stones in Europe; may be found in the Ukrainian Carpathians on eutrophic silicate stones)

\section{(Carbonea latypizodes (Nyl.) Knoph \& Rambold)}

1. Carbonea aggregantula (Müll. Arg.) Diederich \& Triebel in Diederich, Herzogia, 16: 51 (2003) (Fig. 2).

Fig. 2. Carbonea aggregantula (white arrows) on thallus of Lecanora polytropa. Bar $500 \mu \mathrm{m}$

Рис. 2. Carbonea aggregantula (білі стрілки) на слані Lecanora polytropa. Шкала 500 мкм

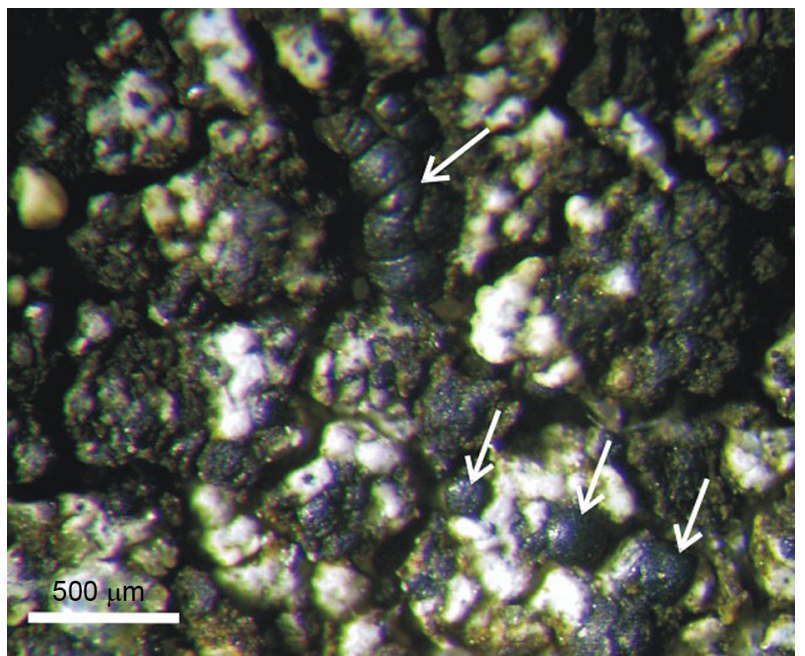

Life form: lichenicolous fungus. Thallus: non-lichenized, immersed and indistinct in host thallus or absent. Apothecia: numerous, dispersed to aggregated in small groups, superficial, sessile, strongly convex to hemispheric, glossy, without margin, similar to some species of Arthonia, 0.2-0.25 mm in diam., round to angular in groups. Exciple: black in vertical section. Epihymenium: blue-green (black with blue-green tinge in lower part on thick section). Hymenium: colourless in central part, blue-green above and brownish in lower part, 45-50 $\mu \mathrm{m}$ high. Green pigment in hymenium and epihymenium $\mathrm{N}+$ purple-red. Hypothecium: black-brown not distinguished from the exciple, about $70 \mu \mathrm{m}$ high. Hamathecium: paraphyses simple and conglutinated, 1-2 $\mu \mathrm{m}$ thick, apical cell blue-green, swollen to $2.5 \mu \mathrm{m}$. Asci: clavate with tall apical dome, of the Lecanora-type (see Fig. 1, A), 35-45×13-15 $\mu \mathrm{m}$, 8-spored (sometimes 4-spored; [1]). Ascospores: colourless, simple (sometimes with thin septum; [1]), fusiform to bacilliform with obtuse apices, 9-12×2-4 $\mu \mathrm{m}$ (see Fig. 1, B). Pycnidia: not seen in the Ukrainian sample.

Ecology: Grows on thallus of Lecanora polytropa (Ehrh.) Rabenh. and sometimes on thallus of Candelariella spp. on silicate rocks in subalpine and alpine regions [1].

Distribution: Europe, Asia, Southern America, Australia, Antarctica [1].

Examined specimen: Zakarpats'ka oblast, Rakhiv district, Chornohora Mts, Mt Petros, on thallus of Lecanora polytropa on rock, 14.07.2011 M. Pirogov, 1894 (LW). New to Ukraine.

ISSN 1996-4536 (print) • ISSN 2311-0783 (on-line) • Біологічні Студії / Studia Biologica • 2014 • Том 8/№1 • С. 137-148 
2. Carbonea assimilis (Hampe ex Körb.) Hafellner \& Hertel in Wirth, Die Flecht. Baden-Württembergs. Verbreitungsatlas (Stuttgart): 511 (1987).

Life form: lichenicolous or free-living lichen. Thallus: light-brown to brown-yellow, usually dark and glossy, areolate. Areoles $0.3-1.6 \mathrm{~mm}$ in diam., strongly convex, 0.1-0.8 mm high. Prothallus present. Apothecia: scattered or aggregated in groups, on margin of areoles, sessile with incised base, glossy, angular by pressure, black, with thin flexuous prominent margin, concave to slightly convex, $0.4-0.8 \mathrm{~mm}$ in diam. Exciple: dark-brown or black in central part and green-black or olive in marginal part in vertical section. Epihymenium: bright blue-green, N+ purple-red. Hymenium: colourless to greenish above, 45-65 $\mu \mathrm{m}$ high. Hypothecium: colourless, 50-150 $\mu \mathrm{m}$ high. Hamathecium: paraphyses simple and conglutinated, frequently anastomosed, 1-2 $\mu \mathrm{m}$ thick, apical cell swollen to $2.5 \mu \mathrm{m}$. Asci: clavate with tall apical dome, of the Lecanora-type, 35-43×12-17 $\mu \mathrm{m}$. Ascospores: simple, broadly ellipsoid to ovoid, 8-15×5-9.5 $\mu \mathrm{m} .[1 ; 12]$.

Ecology: Starting as a lichenicolous lichen on various species, e.g. Aspicilia spp., Lecanora frustulosa, Lecidea lapicida, Pertusaria pseudocorallina, Rhizocarpon spp., Tephromela atra, later free-living on siliceous rocks; in montane and alpine regions [1]. Ukrainian specimen recorded in Crimea from the thallus of Diploschistes actinostomus (Ach.) Zahlbr. on schist [12].

Distribution: Europe, Asia, Northern America, [1].

3. Carbonea supersparsa (Nyl.) Hertel in Mitt. bot. StSamml., Münch. 19: 442 (1983) (Fig. 3).

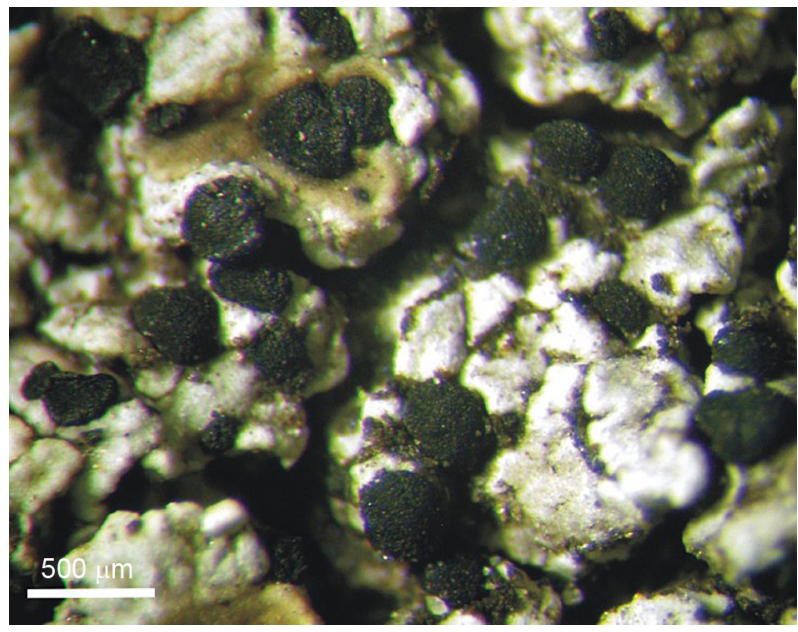

Fig. 3. Carbonea supersparsa on thallus and apothecium of Lecanora sulphurea. Bar $500 \mu \mathrm{m}$

Рис. 3. Carbonea supersparsa на слані й апотеціях Lecanora sulphurea. Шкала 500 мкм

Life form: lichenicolous fungus. Thallus: indistinct in thallus and apothecia of the host. Apothecia: aggregated in small groups on host areoles, adnate or immersed in the thallus of the host, black, round or angular, flat to slightly convex, slightly glossy or matt, 0.25-0.7 $\mathrm{mm}$ in diam. Margin prominent in young apothecia, but disappearing in old apothecia. Exciple: brown to dark-brown above in vertical section, N+ purple. Epihymenium: blue-green, dark green (dark-brown with green tinge in lower part on thick section), about $7 \mu \mathrm{m}$ high. Hymenium: colourless in lower part, olive-green to blue-

ISSN 1996-4536 (print) • ISSN 2311-0783 (on-line) • Біологічні Студії / Studia Biologica • 2014 • Том 8/№1 • C. 137-148 
green in upper part, about $40 \mu \mathrm{m}$ high. Green pigment in hymenium and epihymenium $\mathrm{N}+$ purple-red. Hypothecium: colourless to yellowish, about $30 \mu \mathrm{m}$ high. Hamathecium: paraphyses simple and conglutinated, 1-2 $\mu \mathrm{m}$ thick, apical cell swollen to $3.5 \mu \mathrm{m}$. Asci: clavate with tall apical dome and of the Lecanora-type, 30-40×15 $\mu \mathrm{m}$, 8-spored. Ascospores: colourless, simple, ellipsoid to ovoid-fusiform with obtuse apices, 7-12×4-6 $\mu \mathrm{m}$ (see Fig. 1, C). Pycnidia: not seen in the Ukrainian sample.

Ecology: On thallus and apothecia of Lecanora polytropa, L. intricata, L. sulphurea and Rhizoplaca subdiscrepans on silicate rocks in montane and apline regions [1].

Distribution: Europe, Northern America [1].

Examined specimen: Zakarpats'ka oblast, Rakhiv district, Chornohora Mts, Mt Petros, on thallus and apothecia of Lecanora sulphurea (Hoffm.) Ach., 14.07.2011, M. Pirogov, 1897 (LW). New to Ukraine.

4. Carbonea vitellinaria (Nyl.) Hertel in Mitt. bot. StSamml., Münch. 19: 442 (1983) (Fig. 4).

Life form: lichenicolous non-lichenized fungus. Thallus: indistinct in host thallus. Apothecia: dispersed to aggregated on host thallus, black, adnate, slightly glossy, with granular surface, slightly concave to convex, $0.25-0.4 \mathrm{~mm}$ in diam. Young apothecia round, with prominent margin, old apothecia in tight groups, angular, with slightly apparent margin or without margin. Exciple: dark-brown in inner part and black in marginal part in the vertical section, $\mathrm{N}+$ purple. Epihymenium: blue-green (black with blue-green tinge in lower part on thick section), about $10 \mu \mathrm{m}$ high. Green pigment in hymenium and epihymenium $\mathrm{N}+$ purple-red. Hymenium: colourless, in upper part blue-green, about $40 \mu \mathrm{m}$ high. Hypothecium: colourless in upper part, light-brown to dark-brown in lower part, not distinguished from exciple, about $65 \mu \mathrm{m}$ high. Hamathecium: paraphyses simple and conglutinated, 1-2 $\mu \mathrm{m}$ thick, apical cell swollen to $2.5 \mu \mathrm{m}$. Asci: clavate with tall apical dome, 8-spored. Ascospores: colourless, simple, ellipsoid to ovoid with round apices, 7-11×4-6 $\mu \mathrm{m}$ (see Fig. 1, D). Pycnidia: not seen in the Ukrainian sample.

Fig. 4. Carbonea vitellinaria on thallus of Candelariella vitellina. Bar $500 \mu \mathrm{m}$

Рис. 4. Carbonea vitellinaria на слані Candelariella vitellina. Шкала 500 мкм

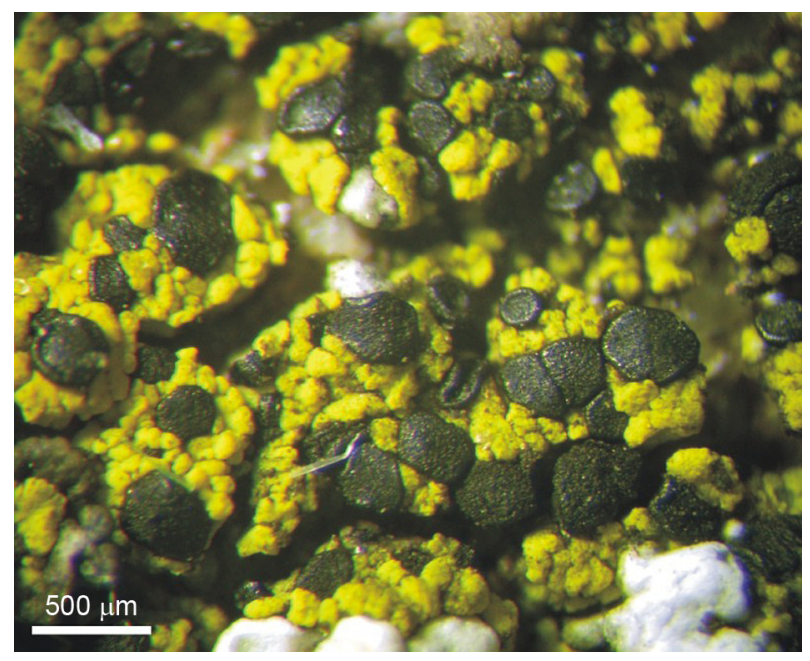

ISSN 1996-4536 (print) • ISSN 2311-0783 (on-line) • Біологічні Студії / Studia Biologica • 2014 • Том 8/№1 • С. 137-148 
Ecology: Lichenicolous on thallus of silicicolous Candelariella (usually), Lecanora, Lecidea and Rhizocarpon. Distributed in montane and alpine regions, rarely in lowland [1].

Distribution: Arctic, Europe, Asia, Northern America [1].

In Ukraine, it is known from Crimea [5], the Lviv region [4] and the Carpathians (this paper).

Examined specimen: Zakarpats'ka oblast, Rakhiv district, Chornohora Mts, Mt Petros, on thallus of Candelariella vitellina (Ehrh.) Müll. Arg., 14.07.2011, M. Pirogov, 1898 (LW).

5. Carbonea vorticosa (Flörke) Hertel in Mitt. bot. StSamml., Münch. 19: 442 (1983). Syn.: Lecidea vorticosa (Flörke) Körb. (Fig. 5).

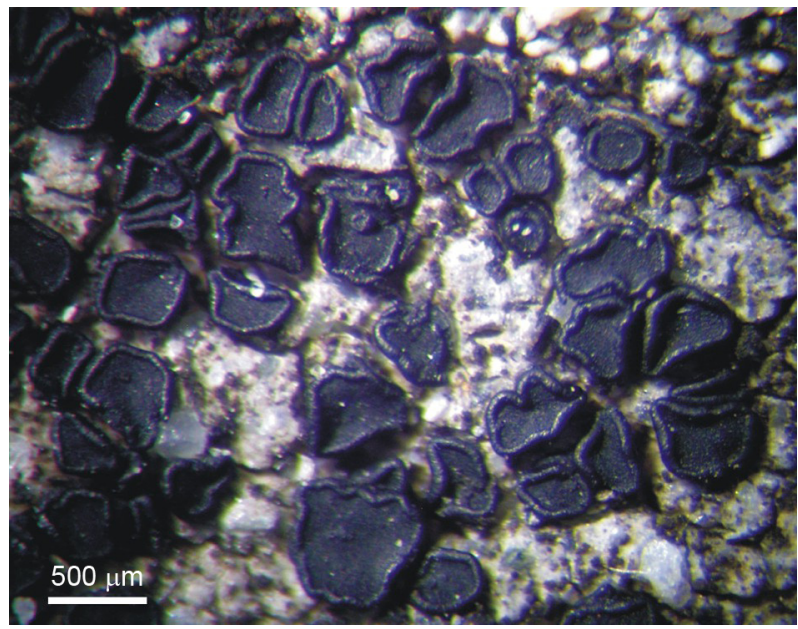

Fig. 5. Carbonea vorticosa. Bar $500 \mu \mathrm{m}$

Puc. 5. Carbonea vorticosa. Шкала 500 мкм

Life form: lichen-forming, not lichenicolous fungus. Thallus: thin, areolate, grey to whitish, consisting of small granules, or frequently strongly reduced. Apothecia: dispersed, rarely aggregated in small groups, sessile, $0.25-1.0 \mathrm{~mm}$ in diam. Young apothecia round, old apothecia in tight groups, angular, with glossy black, distinct and persistent margin, concave to flat, black, with granular surface, sometimes with umbo. Exciple: in inner part dark brown, in outer part pale brown in vertical section, $\mathrm{N}+$ purple. Epihymenium: blue-green to aeruginose-green (black to dark brown with blue-green tinge in lower part on thick section), about 4-5 $\mu \mathrm{m}$ high. Hymenium: colourless to bluish-green above, about $70 \mu \mathrm{m}$ high. Green pigment in hymenium and epihymenium N+ purple-red. Hypothecium: brown-black, paler than exciple, to $120 \mu \mathrm{m}$ high. Hamathecium: paraphyses simple and conglutinated, in upper part branched and anastomosed, thin, apical cell swollen to $3.5 \mu \mathrm{m}$. Asci: clavate with tall apical dome, narrow, 8-spored, 24-50×11-14 $\mu \mathrm{m}$. Ascospores: colourless, simple (perhaps rarely with thin septum; [1]), ellipsoid to oblong with rounded apices, 9-12×4-5 $\mu \mathrm{m}$ (see Fig. 1, E). Pycnidia: not seen in the Ukrainian sample.

Ecology: On siliceous or calcareous outcrops in montane and alpine regions [1]. Distribution: Europe, Asia, Northern and Southern America, New Zealand [1]. In Ukraine, it is known from Crimea [5] and the Carpathians ([3]; this paper). 
Examined specimen: Zakarpats'ka oblast, Rakhiv district, Chornohora Mts, Mt Petros, on silicate rocks, 14.07.2011, M. Pirogov, 1889, 1890-1893, 1895, 1899 (LW).

Scoliciosporum intrusum (Th. Fr.) Hafellner Fritschiana, 49: 31 (2004) (Fig. 6).

Selected synonyms: Carbonea intrusa (Th. Fr.) Rambold \& Triebel; Carbonea invadens sensu Vondrák et al., Chornomors'k. Bot. Z., 6 (1): 15 (2010), non (H. Magn.) M.P. Andreev.

Life form: lichen-forming, lichenicolous (rarely free-living [9]) fungus. Thallus: rimose-areolate, thin, grey, olive to black or indistinct on thallus host. Apothecia: lecideine, black, $0.15-0.5 \mathrm{~mm}$ in diam., with thin flexuous prominent, slightly glossy or matt margin, disc flat to slightly convex, granular, with the true exciple about 40-60 $\mu \mathrm{m}$ wide (in horizontal projection). Exciple: black-blue-green in vertical section, \pm prosoplectenchymatous, glutinized, N+ purple-red, colourless in lower part. Epihymenium: blackgreen, olive-green, N+ red. Hymenium: colourless or olive green, glutinized, 35-50 $\mu \mathrm{m}$ high. Hypothecium: olive-green in upper part, paler to colourless in lower part. Hamathecium: paraphyses about $1.5 \mu \mathrm{m}$ wide, not distinctly thickened at tips; paraphyses strongly tortuous, in spots branched and anastomosed. Asci: 8-spored, with well-developed apical dom, Lecanora-type, about $40 \times 13 \mu \mathrm{m}$. Ascospores: simple or usually 1-2(-3)-septate, narrowly ellipsoid with round apices, colourless, 9-15×3-5 $\mu \mathrm{m}$ (see Fig. 1, F). All olive to olive-black pigments getting green-blue in $\mathrm{KOH}$. Pycnidia: not seen in the Ukrainian sample.

Fig. 6. Scoliciosporum intrusum on thallus of cf. Aspicilia grisea. Bar $500 \mu \mathrm{m}$

Pис. 6. Scoliciosporum intrusum на слані cf. Aspicilia grisea. Шкала 500 мкм

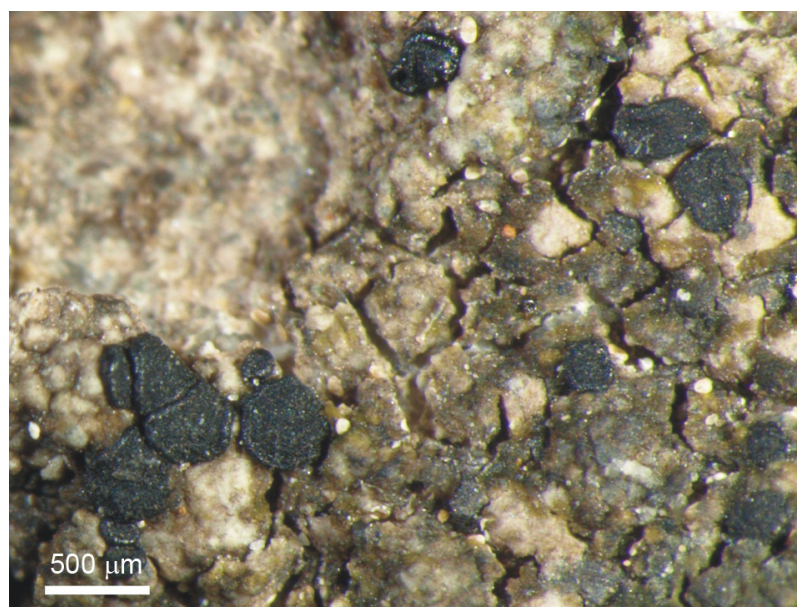

Ecology: Lichenicolous on lichens from genera Amygdalaria, Aspicilia, Calvitimela, Lecidea, Lecidella, Pertusaria, Rhizocarpon, Rinodina, Schaereria, Tephromela. Sometimes free-living in later stages, on siliceous or calcareous rocks or as an epiphyte. Distributed in montane and alpine regions [1].

Distribution: Europe, Asia, Northern America [1; 9].

Examined specimen: Zakarpats'ka oblast, Svidovets Mts., Rachiv, Chorna Tisza, Mt Tataruka, alt. c. $1650 \mathrm{~m}$, on siliceous outcrop at timberline, partly lichenicolous on Lecanora sp. and cf. Aspicilia grisea (sorediate, with norstictic acid), 28.6.2007, J. Vondrák 6774 (CBFS, sub Carbonea invadens). New to Ukraine.

ISSN 1996-4536 (print) • ISSN 2311-0783 (on-line) • Біологічні Студії / Studia Biologica • 2014 • Том 8/№1 • С. 137-148 
Thus, now in Ukraine five species of Carbonea: C. aggregantula (Müll. Arg.) Diederich \& Triebel, C. supersparsa (Nyl.) Hertel (both new to Ukraine), C. assimilis (Körb.) Hafellner et Hertel, C. vitellinaria (Nyl.) Hertel and C. vorticosa (Flörke) Hertel. are known Carbonea invadens (H. Magn.) M.P. Andreev was incorrectly recorded from Ukraine, the respective voucher specimen is Scoliciosporum intrusum (Th. Fr.) Hafellner, a little known taxon similar to Carbonea, also new to Ukraine. Four species, "Lecidea" halacsyi J. Steiner, Carbonea herteliana Hafellner \& Matzer, C. atronivea (Arnold) Hertel and C. latypizodes (Nyl.) Knoph \& Rambold, may be found in Ukraine and thus these species are included in the determination key presented paper.

Acknowledgement: the project was supported by the long-term research development project RVO 67985939 and by the Grant Agency of Faculty of Environmental Sciences, CULS, Prague, 42900/1312/3114.

1. Андреев М.П. Сем. Lecanoraceae Fée emend. Hafellner - Леканоровые. Определитель лишайников России. Вып. 8. Санкт-Петербург: Наука, 2003: 111-184.

2. Кондратюк С.Я., Димитрова Л.В., Надєїна О.В. Зведений список лишайників України (за станом на 2010 р.) та їх репрезентативність у “Флорі лишайників України". Флора лишайників України. Т. 2. Вип. 3. Київ: Наук. думка, 2010: 446-486.

3. Окснер А.М. Флора лишайників України. Т. 2., Вип. 1. Київ: Наук. думка, 1968. 500 с.

4. Пірогов М. Ліхенофрільні гриби Українського Розточчя. Вісник Львів. ун-ту. Сер. біол, 2012; 59: 73-81.

5. Ходосовцев О.Є. Нові для України та Кримського півострова види лишайників з Кримських яйл. Укр. ботан. журнал, 2002; 59(2): 171-178.

6. Grube M., Baloch E., Arup U. A phylogenetic study of the Lecanora rupicola group (Lecanoraceae, Ascomycota). Mycol. Res, 2004; 108(5): 506-514.

7. Hafellner J. Beiträge zu einem Prodromus der lichenicolen Pilze Österreichs und angrenzender Gebiete. IV. Drei neue Arten und weitere bemerkenswerte Funde hauptsächlich in der Steiermark. Linzerbiol. Beitr, 1999; 31: 507-532.

8. Hafellner J. Lecideoid lecanoralean ascomycetes invading Rhizocarpon subgen. Rhizocarpon taxa, with special emphasis on cryptothalline species. Fritschiana (Graz), 2006; 52: 31-48.

9. Hafellner J. Notes on Scoliciosporum intrusum. Fritschiana (Graz), 2004; 49: 29-41.

10. Hertel $\mathrm{H}$. Revision einiger calciphiler Formenkreise der Flechtengattung Lecidea. Beih. Nova Hedwigia, 1967; 24: 1-174.

11. Hertel H. Über einige aus Lecidea und Melanolecia (Ascomycetes lichenisati) auszuschließende Arten. Mitt. Bot. Staatssamml. München, 1983; 19: 441-447.

12. Khodosovtsev A., Vondrák J., Šoun J. New lichenized and lichenicolous fungi for the Crimean peninsula (Ukraine). Chornomorsk. Bot. Z, 2007; 3(2): 109-118.

13. Kirk P.M., Cannon P.F., Minter D.W. and Stalpers J.A. (eds.) Ainsworth and Bisby's Dictionary of the Fungi. $10 \mathrm{Ed}$. Wallingford: CAB International, 2008. $771 \mathrm{p}$.

14. Vondrák J., Palice Z., Khodosovtsev A., Postoyalkin S. Additions to the diversity of rare or overlooked lichens and lichenicolous fungi in Ukrainian Carpathians. Chornomorsk. Bot. Z, 2010; 6(1): 6-34. 


\title{
CARBONEA В УКРАÏHI
}

\author{
М. Пірогов ${ }^{1}$, Н. Чепелевська ${ }^{1}$, Я. Вондрак 2 \\ 1 Львівський національний університет імені Івана Франка \\ вул. Грушевського, 4, Львів 79005, Україна \\ e-mail: nikola.pirogov@gmail.com
}

${ }^{2}$ Iнститут ботаніки Академії наук, Замок, 1, CZ-252 43 Пругоніце, Чеська Республіка Факультет наук Університету Південної Богемії, Бранішовська, 31, CZ-370 05 Чеське Будейовице, Чеська Республіка і Факультет наук про довкілля Чеського університету наук про життя у Празі e-mail:j.vondrak@seznam.cz

Рід Carbonea (Lecanoraceae, Ascomycota) налічує близько 20 видів грибів, як ліхенофільних, так і тих, що формують лишайники, з яких в Україні дотепер було відомо лише чотири види: Carbonea assimilis (Körb.) Hafellner et Hertel, C. vitellinaria (Nyl.) Hertel, C. invadens (H. Magn.) M.P. Andreev i C. vorticosa (Flörke) Hertel. У роботі наведено опис роду, ключ для визначення видів роду, як тих, що вже відомі для України, так і тих, які можуть бути з часом виявлені, крім того, ключ містить і морфологічно подібні види грибів із інших родів. У статті також наведено описи п'яти видів з Українських Карпат і Кримського півострова: C. aggregantula (Müll. Arg.) Diederich \& Triebel, C. supersparsa (Nyl.) Hertel (обидва види наведені для України вперше), C. assimilis, C. vitellinaria і C. vorticosa. Зразки Carbonea assimilis не досліджувались, і опис наведено згідно з літературними даними. Carbonea invadens була некоректно наведена з України, додатково проведені дослідження гербарного зразка цього виду показали, що це Scoliciosporum intrusum (Th. Fr.) Hafellner, слабо відомий таксон, схожий до видів роду Carbonea. Опис цього зразка також наведено у роботі.

Ключові слова: альпійські лишайники, ліхенофільні гриби, біорізноманіття, Карпати, Чорногора, Петрос, Scoliciosporum intrusum.

\section{CARBONEA В УКРАИНЕ}

\author{
Н. Пирогов ${ }^{1}$, Н. Чепелевская ${ }^{1}$, Я. Вондрак² \\ 1 Львовский национальный университет имени Ивана Франко \\ ул. Грушевского, 4, Львов 79005, Украина \\ e-mail: nikola.pirogov@gmail.com
}

${ }^{2}$ Институт ботаники Академии наук, Замок 1, CZ-252 43 Пругонице, Чешская Республика Факультет наук Университета Южной Богемии, Бранишовская, 31, CZ-370 05 Чешске Будеёвище, Чешская Республика и Факультет наук об окружающей среде Чешского Университета наук о жизни в Праге e-mail: j.vondrak@seznam.cz

Род Carbonea (Lecanoraceae, Ascomycota) охватывает около 20 видов грибов, как лихенофильных, так и фрормирующих лишайники, из которых в Украине до сих пор были известны лишь четыре вида: Carbonea assimilis (Körb.) Hafellner et Hertel, C. vitellinaria (Nyl.) Hertel, C. invadens (H. Magn.) M.P. Andreev и C. vorticosa (Flörke)

ISSN 1996-4536 (print) • ISSN 2311-0783 (on-line) • Біологічні Студії / Studia Biologica • 2014 • Том 8/№1 • С. 137-148 
Hertel. В работе приводится описание рода, ключ для определения видов рода, как уже известных для Украины, так и тех, которые, возможно, будут найдены со временем, кроме того, ключ включает и морфологически похожие виды грибов из других родов. В статье также приводятся описания пяти видов из Карпат и Крымского полуострова: C. aggregantula (Müll. Arg.) Diederich \& Triebel, C. supersparsa (Nyl.) Hertel (оба вида новые для Украины), C. assimilis, C. vitellinaria и C. vorticosa. Образцы Carbonea assimilis не изучались, и описание приведено по литературным данным. Carbonea invadens была некорректно описана для Украины, дополнительно проведенные исследования гербарного образца этого вида показали, что это Scoliciosporum intrusum (Th. Fr.) Hafellner, слабо известный таксон, похожий на виды рода Carbonea. Описание этого образца также приведено в работе.

Ключевые слова: альпийские лишайники, лихенофильные грибы, биоразнообразие, Карпаты, Черногора, Петрос, Scoliciosporum intrusum.

Одержано: 04.09.2013

ISSN 1996-4536 (print) • ISSN 2311-0783 (on-line) • Біологічні Студії / Studia Biologica • 2014 • Том 8/№1 • C. 137-148 